\title{
Treatment of Mandibular Large Calcifying Odontogenic Cyst without Grafting: a Case Report
}

\author{
Büyük Kalsifiye Odontojenik Kistin Greftsiz Tedavisi: Olgu Sunumu
}

\author{
Şefik Sinan Kürkçüoğlu, Hasan Mete İnançlı, Ümit Tuncel, Selahattin Genç, ${ }^{1}$ Yetkin Ağaçkıran ${ }^{2}$ \\ Department of Otorhinolaryngology, Oncology Training and Research Hospital; ${ }^{1}$ Department of Otorhinolaryngology, Ulus State \\ Hospital; ${ }^{2}$ Department of Pathology, Atatürk Chest Diseases and Chest Surgery Training and Research Hospital, all in Ankara
}

Submitted/Başvuru tarihi: 18.09.2008 Accepted/Kabul tarihi: 07.11.2008

\begin{abstract}
Odontogenic cysts in the jaw are usually located in the mandibular ramus and corpus. In histopathological examination, they are characterized with palisading in the basal layer and large keratinized 'ghost' cell tumor appearance. Odontogenic cysts are important due to their quick growth clinically and pathologically and their high rate of recurrence. Various surgical techniques may be used in its treatment.The 56-year-old male patient admitted to our clinic with complaints of a nodule in his mandibular corpus and intermittent leakage was found to have a $5 \times 5 \mathrm{~cm}$. hard and smooth tumor. The tumor was removed by dissection from the mandibula together with its periosteal and capsule. The pathological examination led to the diagnosis of a calcifying odontogenic cyst. No recurrence was seen during the two-year follow-up of the patient. In our case, no recurrence was seen in the clinical follow-up for two years after the operation. This means that odontogenic cyst treatment is possible without grafting. We would like to focus the interest on surgical treatment of a calsifying odontogenic cyst surgery is possible without grafting and mandibular prosthesis implantation. In this way, graft resorption or implant complications may be avoided.

Key words: Calcifying odontogenic cyst; mandibular prosthesis implantation; mandibular neoplasms.
\end{abstract}

Çenede gelişim gösteren odontojenik kistler sıklıkla mandibula ramus'u ve korpus'unda yerleşim göstermektedir. Histopatolojik incelemelerinde bazal tabakada palizatlaşma ve geniş keratinize 'ghost' hücre kitle görünümü ile karekterizedirler. Odontojenik keratokist'ler klinik ve patolojik olarak hızlı büyüme ve yüksek oranda tekrar oluşum göstermeleri sebebiyle önemlidirler. Tedavide ise farklı cerrahi teknikler uygulanabilmektedir. Kliniğimize mandibula korpus'unda şişliği olan ve aralıklarla akıntısı olduğunu ifade eden 56 yaşında erkek hastanın yapılan muayenesinde $5 \times 5 \mathrm{~cm}$ büyüklüğünde sert düzgün yüzeyli bir kitlesi olduğu tesbit edildi. Kitle periost ve kapsülü ile birlikte mandibula'dan diseke edilerek total olarak çıkarıldı. Patolojik incelemede "kalsifiye odontojenik keratokist" tanısı kondu. Hastanın iki yıl boyunca takibi sırasında herhangi bir tekrar oluşuma rastlanmadı. Greftlemelemeye gerek kalmadan odontojenik kist tedavisi mümkündür. Biz bu vakada greftlemeye ya da herhangi bir implant intiyacı olmadan büyük bir kalsifiye odontojenik kistin eksiyonunun mümkün olduğunu göstermeye çalıştık. $\mathrm{Bu}$ yaklaşımla olası greft ya da mandibula protezi komplikasyonlarından hastayı korumuş olduk.

Anahtar sözcükler: Kalsifiye odontojenik kist; mandibula protezi; mandibuler neoplaziler.

Presented at the 29th Turkish National Otorhinolaryngology and Head \& Neck Surgery Congress, May 26-31, 2007, Antalya, Turkey (29. Türk Ulusal Kulak Burun Boğaz ve Baş Boyun Cerrahisi Kongresi'nde sunulmuştur, 26-31 Mayıs 2007, Antalya).

Correspondence (IIletişim adresi): Dr. Şefik Sinan Kürkçüoğlu. Sağlık Bakanlığı Onkoloji Eğitim ve Araştırma Hastanesi Kulak Burun Boğaz, o6460 Ankara, Türkiye. Tel: 0312 - 2363538 Fax (Faks): 0312 - 3363439 e-mail (e-posta): drskurkcuoglu@hotmail.com

(c) Trakya Üniversitesi Tıp Fakültesi Dergisi. Ekin Tıbbi Yayıncıık tarafından basılımıstır. Her hakkı sakıdır.

(c) Medical Journal of Trakya University. Published by Ekin Medical Publishing. All rights reserved. 
Calcifying Odontogenic ceratocyst (COC) account for approximately $3-17 \%$ of all odontogenic cysts in the jaw..$^{[1]}$ They are most commonly observed in the mandibular ramus and angulus mandibularis. ${ }^{[2]}$ Histopathologically, they are characterized by palisading in the basal layer and a large keratinized 'ghost' cell tumor appearance. ${ }^{[3]}$ Some examples have been shown to resemble ameloblastomas and craniopharyngiomas, however they are distinguished from these by the existence of 'ghost' cells and dentinoids. This rare lesion is significant due to its clinically and pathologically uncommon growth pattern and its high recurrence rate. ${ }^{[4]}$ Recurrence is mostly seen within the first five years after the treatment. Recurrence rates can be as high as $62 \% .^{[5]}$

Vedtofte et al. ${ }^{[6]}$ found in their study that the dental lamina accompanied the cyst membrane and the debris between the mucosa surrounding it. It was also reported that $\mathrm{COC}$ is generally associated with the surrounding soft tissue. In $\mathrm{COC}$, teeth loss and dissolution in the roots may be seen. They resemble ameloblastomas; therefore, age, localization of the lesion, radiographies and tendency for recurrence need to be closely examined. ${ }^{[7]}$

Five to ten years of non-occurrence following the surgery is considered successful. ${ }^{[7]}$ The aspiration and histopathological examination of the cyst liquid is absolutely necessary prior to the operation for biopsy and diagnosis.

Due to the high rate of recurrence, many surgeons curate the mucosa and the bones surrounding the cyst. ${ }^{[7]}$ Many different surgical techniques ranging from marsupialisation to block resection and grafting may be used. But we prefer surgical treatment of a calsifying odontogenic cyst surgery without grafting and mandibular prosthesis implantation. In this way, graft resorption or implant complications may be avoided.

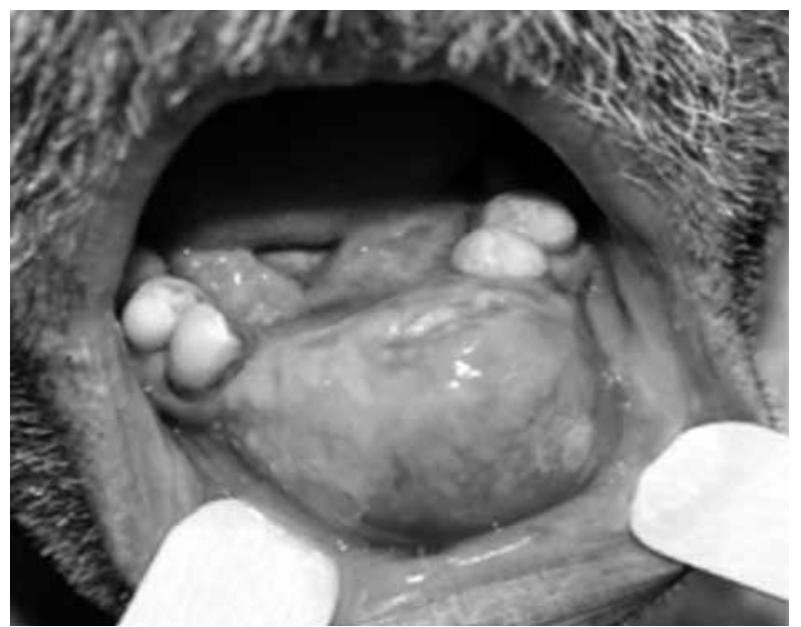

Fig. 1. The approximately $5 \times 5 \mathrm{~cm}$ tumor in the mandibular corpus seen in physical examination.

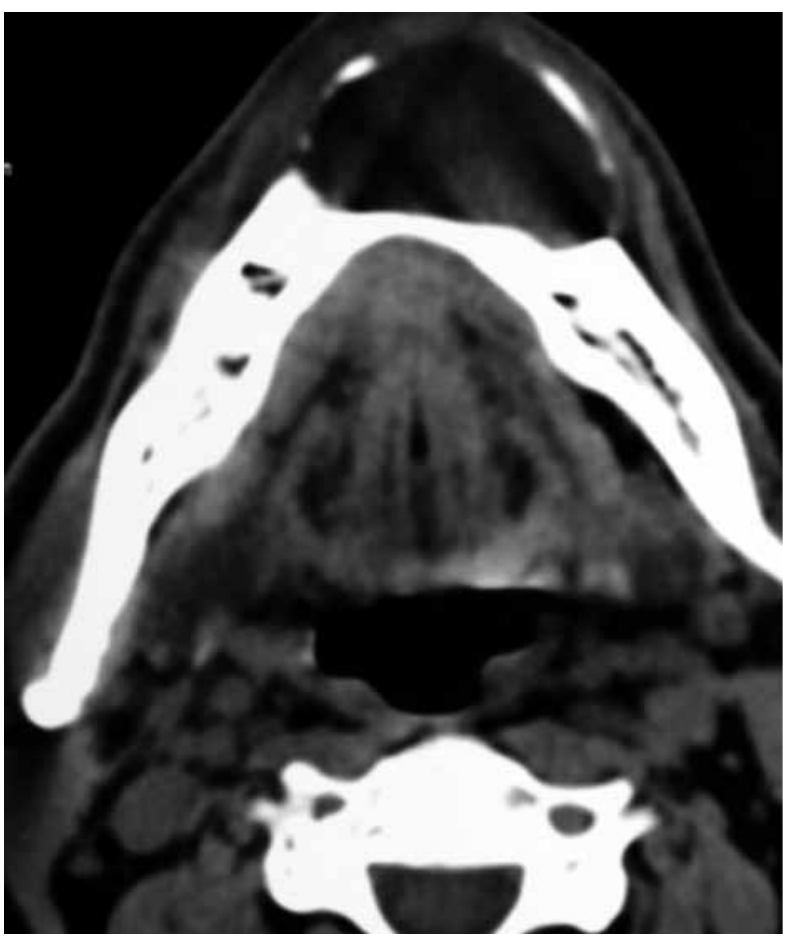

Fig. 2. Computerized tomographical image of hypodense cystic lesion that has expanded and eroded the bone cortex.

\section{CASE REPORT}

The 56-year-old male patient admitted to Dr. Abdurrahman Yurtaslan Oncology Training and Reseach Hospital Ear, Nose and Throat Clinic reported that a nodule started in the middle section of the lower jaw approximately 1.5 years ago and grew slowly. This nodule burst naturally every 3-4 months and released a yellow, transparent liquid, followed by relative shrinking. He also reported that he had lost his teeth over the nodule (Fig. 1). Informed was signed by the patient.

On examination of the patient, a hard and smooth tumor was found in the mandibular corpus, approximately $5 \times 5 \mathrm{~cm}$ in extent. Debris from the roots of the eroded teeth was present on the tumor. The non-opaque material high resolution tomographical examination of the maxillofacial area, showed an approximately $4 \times 4$ $\mathrm{cm}$ hypodense cystic lesion in the mandibular anterior of the patient. The cystic lesion had thinned and occasionally eroded the bone cortex by expanding it. The cyst was rimmed by thin, smooth contoured bone on the periphery and was not accompanied by a soft tissue component. Other structures seemed normal (Fig. 2).

Four $\mathrm{ml}$ of opaque yellow fluid was released from the cyst by thin needle aspiration, after which the cyst partially reduced in size. During injection, slight hardness was observed on the thinned bone wall. The cytomorphological findings were congruent with benign odontogenic 


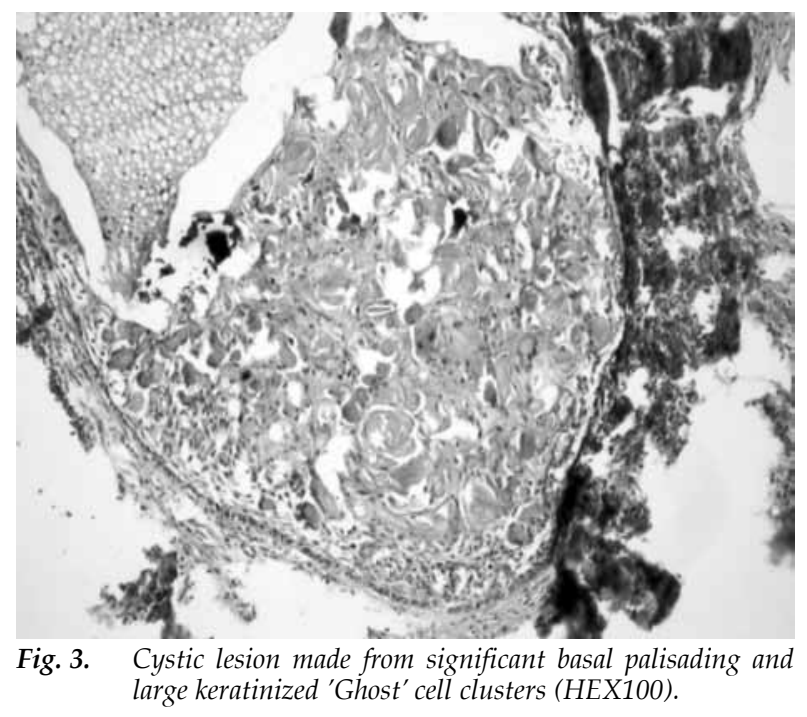

cyst. Biopsy including approximately $0.5 \times 1 \mathrm{~cm}$ mucosa and the thin bone lamella underneath was performed and the patient was diagnosed with cementoblastoma.

Under general anesthesia, the patient's mouth was opened with retractor. The incision performed from the front upper side of the tumor was advanced to the gingivobuccal sulcus on both sides on one level with the first premolar teeth.

The mucosa on the front face of the tumor was elevated. By continuing the elevation from the bottom and sides, we reached the bone tissue. The inner face of the mandibula was found to be undamaged. The tumor was dissected totally from the mandibula together with the periosteum.

The front face of the mentum was found to be destructive and the back face undamaged. The destructive bone debris was curetted and later the bone surface was toured until the undamaged bone tissue was reached by using diamond burr micro tour.

After ensuring homeostasis, the mucosa flap was saturated primarily with $0 / 3$ vicryl. The pathological examination of the removed tumor led to its diagnosis as Calcifying Odontogenic Cyst (COC) (Fig. 3).

Until postoperative tissue recovery was achieved, the patient used bicarbonated gargle and 7.5\% polyvinylpyrrolidone iodine complex.

\section{DISCUSSION}

In our case, we used block resection to an unusually big COC. Following the resection, we did not use grafting which is usually considered necessary. No recurrence was seen in the follow-ups in the first year. Brondum and Jensen ${ }^{[4]}$ found 3\% likelihood of recurrence in the first year following the operation. Forssell et al ${ }^{[8]}$ also reached similar conclusions.
Bataineh et al. ${ }^{[2]}$ reported that enucleation was rather difficult as the cyst wall was too thin and the mandibula thickness was too shallow. In our patient too, the mandibula was rather thin but enough support was present. Bataineh et al. ${ }^{[2]}$ also reported that recurrence occurred because the cyst wall disintegrated due to its thinness and fragility, and residue was left due to improper cleaning of the bone cortex in the tours. We paid attention not to interfere with the cyst's entirety while removing it and we properly toured the bone cortex to its borders.

Many studies prefer marsupialization to avoid recurrence. Despite this, success has been reported in certain cases by using enucleation and marsupialisation. This technique is rather conservative. We did not prefer marsupialisation due to frequent recurrence. Irvine et al., ${ }^{[7]}$ prefer radical enucleation and bone grafting in large keratocysts. We did not prefer grafting as sufficient bone cortex remained for future prostheses after the radical block removal of the cyst and the touring.

Decompression and cystectomy are also useful methods of treatment. In a study with 12 cases, no recurrence was observed in the 7-17 years following decompression and cystectomy ${ }^{[9]}$ The disadvantage of the method is the need for two-stage surgery and the prolonged treatment time. We therefore did not use this technique in our case.

Dammer et al. ${ }^{[5]}$ preferred simple excision in small $\mathrm{COC}$ and radical excision reaching as far as normal tissue in large COC. Similarly, we performed excision and touring without destroying the entirety of the cystic wall both mucosal and to the boundaries of undamaged bone. In spite of all this, recurrence may be seen even 20-40 years after the treatment. ${ }^{[10]}$

In this study, we employed the intraoral approach to treat a large COC without using any extra techniques, destroying the entirety of the cyst, placing a bone graft in the mandibula or damaging the cosmetic appearance and mandibular chewing function of the patient.

There is much research and debate concerning the formation, growth and treatment of odontogenic calcifying keratocysts. Histopathologically, it is typical to display 'ghost cells'. The use of imaging methods in treatment, undertaking biopsies and choosing appropriate surgical techniques are important factors in avoiding recurrence. This type of treatment does not affect the chewing function as much as surgical treatment with grafting. The surgical method is also important for the life quality of the patient. In our case, no recurrence was seen in the clinical follow-up for two years after the operation. This means that odontogenic cyst treatment is possible without grafting. This finding may imply that grafts or mandibular prosthesis implantations may not be necessary in the surgical treatment of COC. In this 
way, graft resorption or implant complications may be avoided.

\section{REFERENCES}

1. Altini M, Farman AG. The calcifying odontogenic cyst. Eight new cases and a review of the literature. Oral Surg Oral Med Oral Pathol 1975;40:751-9.

2. Bataineh $A B$, al Qudah M. Treatment of mandibular odontogenic keratocysts. Oral Surg Oral Med Oral Pathol Oral Radiol Endod 1998;86:42-7.

3. Barry $\mathrm{CP}$, Kearns GJ. Case report--odontogenic keratocysts: enucleation, bone grafting and implant placement: an early return to function. J Ir Dent Assoc 2003;49:83-8.

4. Brøndum N, Jensen VJ. Recurrence of keratocysts and decompression treatment. A long-term follow-up of fortyfour cases. Oral Surg Oral Med Oral Pathol 1991;72:265-9.
5. Dammer R, Niederdellmann H, Dammer P, Nuebler-Moritz $M$. Conservative or radical treatment of keratocysts: a retrospective review. Br J Oral Maxillofac Surg 1997;35:46-8.

6. Vedtofte P, Praetorius F. Recurrence of the odontogenic keratocyst in relation to clinical and histological features. A 20-year follow-up study of 72 patients. Int J Oral Surg 1979;8:412-20.

7. Irvine GH, Bowerman JE. Mandibular keratocysts: surgical management. Br J Oral Maxillofac Surg 1985;23:204-9.

8. Forssell K, Forssell H, Kahnberg KE. Recurrence of keratocysts. A long-term follow-up study. Int J Oral Maxillofac Surg 1988;17:25-8.

9. Shear M. Developmental odontogenic cysts. An update. J Oral Pathol Med 1994;23:1-11.

10. Shafer WG, Hine MK, Levy BM, editors. A textbook of oral pathology. 4th ed. Philadelphia: Saunders; 1983. 